\title{
Effect of naked oats and enzyme supplementation on performance of hens and quality traits of eggs
}

\author{
M. Fabijańska ${ }^{1,3}$, M. Boruta ${ }^{2}$, J.L. Sokół ${ }^{1}$, A. Hermanowska ${ }^{1}$ \\ and M. Chojecka ${ }^{1}$
}

Warsaw Agricultural University,

${ }^{1}$ Department of Animal Nutrition and Feed Science,

${ }^{2}$ Department of Poultry Science

Ciszewskiego 8, 02-786 Warsaw, Poland

\begin{abstract}
The experiment was conducted on 192 Hy-Line hens at the age of 25 weeks, divided into 3 groups, 64 individually caged birds per group. Three diets were prepared: the control diet contained $450 \mathrm{~g}$ maize per $\mathrm{kg}$, in two experimental diets maize was replaced by naked oats with or without the addition of an enzymatic preparation containing $\beta$-glucanase. Performance was recorded for 14 weeks; in the 5th week 30 eggs were collected from each group and their interior quality parameters were determined. Neither naked oats nor enzyme supplementation significantly affected performance parameters. The naked oats had no significant effect on the weight of eggs (62.8 $\mathrm{g}$ on average), albumen quality (74 Haugh units on average) and yolk weight, but decreased the shell weight by 0.6 percentage points and yolk colour by 0.7 points on the 15 -point Roche scale.
\end{abstract}

KEY WORDS: naked oats, $\beta$-glucanase, laying hens, eggs

\section{INTRODUCTION}

The presence of $\beta$-glucans that form viscous gels in the alimentary tract can limit the use of naked oats in poultry diets (Jamroz et al., 1994; Svihus and Gullord, 2002). The viscosity of intestinal contents decreases after exogenous enzyme supplementation (Aimonen and Uusi-Rauva, 1991; Boros, 1997).

The aim of the study was to evaluate the effect of complete replacement of maize by naked oats in a laying hen diet and of $\beta$-glucanase supplementation on the laying rate and internal quality of eggs.

\footnotetext{
${ }^{3}$ Corresponding author: e-mail: fabijanska@alpha.sggw.waw.pl
} 


\section{MATERIAL AND METHODS}

Three groups of 64 individually caged 25-week-old Hy-Line hens were fed diets containing $450 \mathrm{~g}$ yellow maize (control) or $450 \mathrm{~g}$ of naked oats per $\mathrm{kg}$. The diet with naked oats was unsupplemented or supplemented with the enzymatic preparation Avizyme 1200, containing $\beta$-glucanase. The diets contained neither grass- lucerne meal or any pigment additives. Details of methodology and nutritional value of diets were described by Sokól et al. (2004). The experiment was carried out for 14 weeks. Eggs were collected daily, the laying rate was calculated. In the fifth week of the experiment 30 eggs from each group were randomly collected. On the next day the eggs were weighed and broken, the colour of yolks compared with a 15-strip Roche colour fan, the height of the thick albumen was measured, yolks and shells were weighed. The Haugh unit value (HU) was calculated according to the equation:

$$
\mathrm{HU}=100 \log \left(\mathrm{H}-1.7 \mathrm{~W}^{0.37}+7.6\right)
$$

where $\mathrm{H}$ is the maximum height of the thick white in $\mathrm{mm}$; $\mathrm{W}$ is the weight of the egg in grams.

The shell index was calculated according to the equation:

Shell index $=$ shell weight $(\mathrm{g}) /$ shell area $\left(\mathrm{cm}^{2}\right) \times 100$

where shell area $=4.68 \times$ shell weight ${ }^{2 / 3}$

The results of the experiment were subjected to one-way analysis of variance (SPSS 10.0).

\section{RESULTS AND DISCUSSION}

The laying rate in the control group was high $(93.2 \%)$, in the groups fed both diets with naked oats it was slightly lower (91.3 and 91.7\%, respectively), while daily feed intake was similar in all groups and equalled about $135 \mathrm{~g} / \mathrm{bird}$. Also Kosieradzka (1999) reported that quails fed a diet with a high level of naked oats had a tendency towards lowering laying performance. Supplementation of the naked oat diet with $\beta$-glucanase did not improve the laying rate significantly.

The replacement of maize with naked oats in the diets for hens had no effect on egg weight, quality of thick albumen, yolk weight or the content of yolk (Table 1). Kosieradzka (1999) also did not find any differences in the value of these parameters in eggs of quails fed a diet with $50 \%$ naked oats. The colour of yolks was acceptable in all groups, but the yolks from the group fed with naked oats were paler than yolks from the control group $(\mathrm{P}<0.05)$ fed the maize diet. Yellow maize, used in the control diet, is a good source of xanthophylls, it seems that naked oats had less xanthophylls, however, due to supplementation of this diet with $\beta$-glucanase the yolks were slightly better coloured.The unfavourable 
effect of a high proportion of naked oats in hen diets on the yolk colour was also reported by Cave et al. (1992) and in quails by Kosieradzka (1999).

Table 1. Performance and quality of eggs

\begin{tabular}{lcccc}
\hline \multirow{2}{*}{ Item } & \multicolumn{3}{c}{ Dietary treatment } & \multirow{2}{*}{ SEM } \\
\cline { 2 - 4 } & Maize & Oats & Oats + enzyme & $*$ \\
Laying rate, \% & 93.2 & 91.3 & 91.7 & 0.84 \\
Egg weight (W), g & 62.8 & 62.7 & 92.9 & 0.67 \\
Quality of thick albumen, HU & 73.9 & 73.8 & 74.0 & 0.20 \\
Yolk colour & $10.6^{\mathrm{a}}$ & $9.9^{\mathrm{b}}$ & $10.0^{\mathrm{a}}$ & 0.22 \\
Yolk weight, g & 15.3 & 15.5 & 15.0 & 0.30 \\
Yolk content, \% W & 24.4 & 24.8 & 24.7 & 0.15 \\
Shell content, \% W & $9.9^{\mathrm{a}}$ & $9.9^{\mathrm{a}}$ & $9.3^{\mathrm{b}}$ & 0.13 \\
Shell index & $8.6^{\mathrm{a}}$ & $8.7^{\mathrm{a}}$ & $8.2^{\mathrm{b}}$ & \\
\hline
\end{tabular}

a,b - means in rows marked with different letters differ significantly at $\mathrm{P} \leq 0.05$

* - not analysed

The percentage content of the shell was lower $(\mathrm{P}<0.05)$ and the quality of the shell, as measured by the shell index, was significantly worse $(\mathrm{P}<0.05)$ in the group fed the naked oat diet supplemented with the enzymatic preparation, as compared with both remaining groups. Deterioration of shell quality due to the addition of the enzymatic preparation to diets containing oats was also reported by Aimonen and Uusi-Rauva (1991) and Kosieradzka (1999).

\section{CONCLUSIONS}

Naked oats may replace maize in diets for laying hens without adversely affecting egg interior quality. Supplementing such diets with enzyme preparations containing $\beta$-glucanase is not necessary and may decrease shell quality.

\section{REFERENCES}

Aimonen E.M., Uusi-Rauva E., 1991. Replacement of barley by oats and enzyme supplementation in diets for laying hens. Acta Agr. Scand. 41, 193-205

Boros D., 1997. Dietary fibre in poultry feeding (in Polish). Proceedings of Conference "Dietary Fibre - Chemical Composition and Biological Activity". Radzików (Poland), pp. 141-155

Cave N.A., Poste L.M., Butler G., Farnworth E.E., Barrows V.D., 1992. Effect of dietary level of naked oats (Avena nuda) on internal and sensory quality of eggs and on yolk lipid composition. Can. J. Anim. Sci. 72, 147-153

Jamroz D., Wiliczkiewicz A., Orda J., Skorupińska J., 1994. Ileale und postileale Fermentation von Getreide-Kohlenhydraten bei Jungmastgeflügel. Wien. Tieräztl. Monatsschr. 81, 80-84

Kosieradzka I., 1999. Evaluation of possibilities of employing Polish naked oat grain in feeding of monogastric animals (in Polish). PhD. Thesis, Warsaw Agricultural University, Warszawa (Poland) 
Sokół J.L., Niemiec J., Fabijańska M., 2004. Effect of naked oats and enzyme supplementation on egg yolk fatty acid composition and performance of hens. J. Anim. Feed Sci. 13, Suppl. 2, 109112

Svihus B., Gullord M., 2002. Effect of chemical content and physical characteristics on nutritional value of wheat, barley and oats for poultry. Anim. Feed Sci. Tech. 102, 71-92

\section{STRESZCZENIE}

\section{Wpływ owsa nagiego i dodatku enzymu na wyniki produkcyjne kur i cechy jakościowe jaj}

Doświadczenie przeprowadzono na 192 kurach Hy-Line w wieku 25 tygodni, podzielonych na 3 grupy po 64 ptaki, utrzymywane indywidualnie. Przygotowano 3 diety: dieta kontrolna z zawierała 450 g kukurydzy w $1 \mathrm{~kg}$, w 2 dietach doświadczalnych kukurydzę zastąpiono owsem nagim bez lub z dodatkiem preparatu enzymatycznego Avizyme 1200. Przez 14 tygodni mierzono wydajność nieśną, w 5 tygodniu w 30 jajach wybranych z każdej grupy zmierzono masę oraz parametry jakości. Owies nagi stosowany w mieszance, jako jedyne zboże, nie wpłynął istotnie na wyniki nieśności, dodatek preparatu enzymatycznego nie miał istotnego wpływu na wyniki produkcyjne. Owies nagi nie miał także istotnego wpływu na masę jaj (średnio 62,8 g), na jakość białka (średnio 74 jednostki Haugha) i masę żółtka, lecz obniżył masę skorupy o 0,6 punktów procentowych i barwę żółtka o 0,7 punktu w 15-punktowej skali Roche, w porównaniu z grupą kontrolną. 